\title{
Lifestyle Influences on Purchase Decisions and Membership
}

\author{
Aggi Panigoro, Andry Fernandus W, Muhamad Mustofa \\ Magister Manajemen \\ Universitas Pendidikan Indonesia \\ Bandung, Indonesia \\ aggipanigoro1703@student.upi.edu
}

\begin{abstract}
Seeing from the consumer's decisions to choose one membership becoming members of a particular fitness center is based on facility, level of comfort and functionality in the fitness center. As an effort to improve purchasing decisions members, Gold's Gym Braga City Walk Bandung continuously makes efforts and relational marketing strategies. The study is aimed to reveal the lifestyle overview, purchase decisions become members and the extent of the lifestyle influence. The study is descriptive and verification research. The sampling technique used was random sampling and by using the sample formula, 100 respondents obtained. The analysis technique used was correlation coefficient of Pearson product moment, and simple linear regression analysis. The results show that lifestyle and the decisions to become members are at a very high category. The result of the simple regression calculation is equation $\hat{\mathbf{Y}}=\mathbf{1 3 , 8 4 3}$ $+0.517 \mathrm{X}$ obtained by the $\mathrm{R}$-square of $44.00 \%$ in which the lifestyle influence on the decisions to become members is at $\mathbf{4 4 . 0 0 \%}$ while the remaining $\mathbf{5 6 . 0 0 \%}$ are influenced by other factors that not examined by the researchers. Expected to conduct a broader study as to consider other factors that influence the decision to become a member.
\end{abstract}

\section{Keywords - Lifestyle, Purchase Decisions Become Members}

\section{INTRODUCTION}

Sport is one of the factors to support a healthy lifestyle with many functions and benefits. Exercising three to four times a week will be beneficial in most people. Very diverse types of sporting activities ranging from sports Athletics, swimming up to work out at the fitness center.

Fitness center is a wide variety of sports activities in one place. Business in the world of fitness is representation of informal sector enterprises are able to survive until now. Things proved more widespread growth of fitness centers ranging from the low end (medium) such as a fitness center adjacent to the place lived up to the images of high end (secondary and above) as well as in the area of the Mall or shopping center to be in hotels.

At first, the fitness center is only demand by the bodybuilders, but with the passing of time, the gym is now in demand by various groups, the employees, celebrities' employers and students or students. The price offered by the manager of Fitness center highly variable ranging from Rp.750.000 price per month for the middle to upper and middle down to 150,000 and even one of the best fitness center in Indonesia, Celebrity Fitness offers a lifetime membership program by paying Rp. 23 Million [1].

Judging from the phenomenon of the cases, it turns out the major problems facing displacement fitness center is a member. The displacement member is generally based on the tastes and the member's decision. Successful fitness center is providing the best service, use quality products and provide a memorable experience for the member as well as the most important thing is to make customers get the convenience of its own in the gym and decided to become a member in the fitness area.

The higher the desires and interests of consumers chose the higher the fitness center also decided to become a member in his choice of fitness centers. One fitness center with the concept of offering a wide range of quality facilities are Gold's Gym, Gold's Gym itself is at Braga City Walk Bandung in order to change the minds of the public when exercising for entertainment and interest to work out with the concept of being in Braga City Walk. Given Gold's Gym as a fitness center that is preferred by consumers, and therefore Gold's Gym have to create a purchase decision to become a member and the member to sustain. When the fitness business managers do not focus on the needs and desires of consumers, it can be ascertained that the fitness center will be reduced members.

Purchasing decisions is one of the concepts of the science of marketing with the development of the fitness business is getting higher and behavior of the consumer (member) [2] there are six stages of the purchase decision.

The first is the selection of products, they choose to exercise in the fitness center with a variety of options for convenience and completeness exercise in accordance with the wishes of consumers. The second is the selection of the brand, with the level of the selection of brands of fitness centers for the best view of the imaging according to consumer that he decided to become a member of the fitness center. The third is the selection of distribution channels, namely in terms of ease of access easy. The fourth when a member purchases seen as a necessity and when there are promotions with rebates. The fifth is amount of the purchase by the level of frequency, how many hours in a day or a week how many times a workout at the gym. The sixth is a payment method seen from the ease and diversity of payment 
using a credit or debit card to become a member and regular payment every month.

In this case, Gold's Gym entering his lifestyle characteristics by interest by doing promotional events in order to attract the attention of consumers to choose and decide to become a member. A person's lifestyle is a pattern in the world of money reflects the activities, interests and opinions [3]. One of the factors that influences the purchase decision is a personal characteristic that consists of Economic situation, lifestyle, personality and self-concept and age and life cycle stage [2]. Thus the lifestyle is the one to attract the consumer to decide on the product.

Judging from the various cases and problems that occur in the fitness center, the authors chose Gold's Gym located in Braga City Walk Bandung as research objects. Gold's Gym fitness center is classified as belonging to recently which began operating in June 2007. The target market Gold's Gym is the high end community (middle and upper). Gold's Gym itself offers training packages with the member systems.

Solomon note that the indicators of Lifestyle consists of Dimensional Activity, interest, opinion, and demographic [3]. Activity of Gold's Gym is the routine assorted sports activities in accordance with Activity while at Gold's Gym. Interest or the interest of the Fitness center by doing renovations start in terms of interior design, exterior until when there are themes Christmas special day. Valentine and Halloween decorating accordance with the theme. Opinion or opinions made Gold's Gym is doing the best services ranging from customer service, personal trainer to the office boy manner with a friendly smile and hello to the members in order to get the best assessment and the opinion of the Gold's Gym.

Demographic Dimensions conducted by Gold's Gym Fitness is for conducting a minimum age of above 16 years and do a rebate for the status are students or college. Lifestyle himself made Gold's Gym is to position the product as well as new facilities are implemented by Gold's Gym to achieve the satisfaction of its members and obtain the consumer's decision to become a member of Gold's Gym in accordance with the needs and wishes, of the lifestyle is very necessary in order to determine and adjust consumer characteristics views of activity, interest, opinion and demographic.

Gold's Gym has a vision that will provide experience at the highest fitness. And, most of our members have felt that we have inspired them. Gold's Gym mission vision as to provide added value for premium class for its members by seeing changes in lifestyle or their lifestyle.

The problems to be discussed in this research are as follows

- Describing lifestyle that consists of activity, interest, opinion, and demographics at Gold's Gym Bandung.

- How does the member Gold's decision Gym Bandung.

- How much influence lifestyle that consists of activity, interest, opinion, and demographic against the decision of the members at Gold's Gym Bandung either simultaneously or partially.
- The purposes of this study are:

- Lifestyle consisting of activity, interest, opinion, and demographics at Gold's Gym Bandung.

- Decisions Bandung member Gold's Gym.

- Lifestyle consisting of activity, interest, opinion, and demographic against the decision of the members at Gold's Gym Bandung.

\section{THEORETICAL BASIS}

\section{A. Consumer Behavior}

Consumer behavior is a behavior of consumers in search of the purchase, consumption, evaluation, and replacement products and services able to satisfy the needs of consumers [4]. Ali Hasan says that the factors that influence consumer behavior one of them is a lifestyle [5]. Lifestyle factors are essential studied by the company. The failures of many marketing programs are determined by the inability to translate these factors into product design, pricing, positioning and marketing communications programs. With a proper understanding of customer behavior and better serve his customers.

\section{B. Lifestyle}

The pattern of one's life in a world that reflected in the activities, interests and opinions [3]. Lifestyle is the overall pattern of life which is expressed in activities, interests and opinions that interacts with their environment [5]. Lifestyle is a person's pattern of living in the world as expressed in activities, interests, and opinions. It portrays the "whole person" interacting with his or her environment [2].

Categorizes the components of the lifestyle in the form of activity, interest, opinion, and demographic [3]. The purpose of lifestyle marketing is to allow consumers to pursue the ways they choose to enjoy their lives and express their social identity. For this reason a key aspect of this strategy is to focus on the people which are use the product in social settings as desired.

\section{Purchase Decision}

The purchase decision is divided into six stages: Product Selection, Brand Selection, Purchase Channel Selection, Purchase Amount, Time of Purchase, and Payment Methods [2]. Decision making process to purchase can be divided into five stages: Problem Recognition, Search Information, Evaluation of Alternatives, Purchase Decision, and PostPurchase Behavior [2].

Lifestyle is part of consumer behavior in the purchase [6]. The buying decision was also influenced by personal characteristics [2]. Personal factors include age and stage in the life cycle of shoppers, workers and the economic situation, personality and concepts as well as lifestyle and values. 


\section{RESEARCH METHOD}

The study will examine two variables, namely the independent variable and the dependent variable. The independent variable are studied, namely Lifestyle, with sub variables: activity, interest, opinion, and demographic. Then being in the dependent variable is a member of Gold's Gym decision Braga City Walk Bandung.

This study done in the period less than one year, the method used is cross sectional method, the method of research by studying the object in a certain period of time / not sustainable in the long term and with explanatory survey.

In this study, the data source is the whole data obtained from questionnaires distributed to a number of respondents in accordance with the target and is considered to represent the entire population of the research data, namely the members or subscribers of membership at Gold's Gym Braga City Walk Bandung. While the research design used in this research is the design of causality. The ultimate goal is to obtain evidence of a causal relationship, so that becoming known which variables influence and the variables are affected.

Questionnaire, by distributing a set list of written questions to the respondent that the members Fitness Center, Gold's Gym Braga City Walk Bandung. Respondents just choose alternative answers that have been provided on each of the alternative answers that seemed most appropriate. In this questionnaire the authors propose some questions which are elements of the Activity (X1), Interest (X2), Opinion (X3), Demographic (X4) and Decision Member (Y).

This population is restricted to members of the active and inactive members. In the period from June 2007 until April

2016. To use the sample more representative, the sampling technique used was random sampling and by using the sample formula, 100 respondents obtained.

\section{RESULTS AND DISCUSSIONS}

Based on two analyzes including descriptive analysis and statistical analysis for the influence of lifestyle on the decision of the members are:

\section{A. Descriptive analysis}

TABLE I. RESPONDENTS REGARDING RECAPITULATION LIFESTYLE AT GOLD's GYM BRAGA CITY WALK BANDUNG

\begin{tabular}{|l|l|l|l|l|}
\hline No & \multicolumn{1}{|c|}{ Indicator } & $\begin{array}{c}\text { Number of } \\
\text { Question }\end{array}$ & \multicolumn{1}{|c|}{ Score } & $\begin{array}{c}\text { Average } \\
\text { score }\end{array}$ \\
\hline 1. & Activity & 4 & 1618 & 404,5 \\
\hline 2. & Interst & 3 & 1332 & 444 \\
\hline 3. & Opinion & 3 & 1378 & 459 \\
\hline 4. & Demographic & 3 & 1365 & 455 \\
\hline \multicolumn{2}{|l|}{ Total } & $\mathbf{1 3}$ & $\mathbf{5 6 9 3}$ & $\mathbf{1 7 6 2 , 5}$ \\
\hline
\end{tabular}

Source: Data Processing April 2016

According to the table 1 about the picture lifestyle analysis at Gold's Gym Braga City Walk Bandung overall were, in order knowable indicators of lifestyle analysis is predominantly on indicators of opinion that with a total score
According to the table 1 about the picture lifestyle analysis at Gold's Gym Braga City Walk Bandung overall were, in order knowable indicators of lifestyle analysis is predominantly on indicators of opinion that with a total score of 459 this case Due to Gold's Gym has the facility to service are operationally to make the members already believe and assess the best opinion by yourself. Opinion dimension consists of views and opinions of self- concept to product [3]. That if the product is good according to the needs and desires of consumers, the consumer will be found according to what they feel.

TABLE II. RECAPITULATION CONCERNING RESPONDENTS PURCHASING DECISION AT GOLD's GYM BRAGA CITY WALK BANDUNG

\begin{tabular}{|l|l|l|l|l|}
\hline No & \multicolumn{1}{|c|}{ Indicator } & $\begin{array}{c}\text { Number of } \\
\text { question }\end{array}$ & \multicolumn{1}{|c|}{ Score } & $\begin{array}{c}\text { Average } \\
\text { score }\end{array}$ \\
\hline 1. & Product choice & 2 & 887 & 443,5 \\
\hline 2. & Brand choice & 1 & 472 & 472 \\
\hline 3. & Dealer choice & 2 & 760 & 380 \\
\hline 4. & Purchase amount & 2 & 783 & 391,5 \\
\hline 5. & Purchase timing & 2 & 867 & 433,5 \\
\hline 6. & Payment method & 2 & 890 & 445 \\
\hline Total & $\mathbf{1 0}$ & $\mathbf{4 6 5 9}$ & $\mathbf{2 5 6 5 , 5}$ \\
\hline
\end{tabular}

Source: Data Processing April 2016

Based on Table 2 regarding our purchasing decisions or become a member at Gold's Gym Braga City Walk Bandung overall were, in order knowable indicators purchasing decision is the dominant indicator elections brands namely with a total score of 472 this is due to the selection of the brand, the brand Gold's Gym itself already discount included big names and the best fitness center in the mass media. And also Gold's Gym has a mega gym concept that exists around the world. Therefore the respondents are members of Gold's Gym has been felt in accordance with the selecting and maketh Gold's Gym Braga City Walk Bandung as the fitness suite.

\section{B. Statistical analysis}

Simple regression equation using the results of data processing using SPSS 17.0 for Windows

\section{TABLE III. OUTPUT COEFFICIENTS}

\begin{tabular}{|c|c|c|c|c|c|c|}
\hline \multicolumn{7}{|c|}{ Coefficienta $^{a}$} \\
\hline \multirow{2}{*}{\multicolumn{2}{|c|}{ Model }} & \multicolumn{2}{|c|}{$\begin{array}{c}\text { Unstandardized } \\
\text { Coefficients }\end{array}$} & \multirow{2}{*}{$\begin{array}{c}\begin{array}{c}\text { Standardized } \\
\text { Coefficients }\end{array} \\
\text { Beta }\end{array}$} & \multirow[t]{2}{*}{$\mathbf{t}$} & \multirow[t]{2}{*}{ Sig. } \\
\hline & & B & $\begin{array}{c}\text { Std. } \\
\text { Error }\end{array}$ & & & \\
\hline 1 & $\begin{array}{l}\text { (Constant) } \\
\text { LIFESTYLE }\end{array}$ & $\begin{array}{l}13.843 \\
.517\end{array}$ & $\begin{array}{l}2.455 \\
.059\end{array}$ & .664 & $\begin{array}{l}5.640 \\
8.782\end{array}$ & $\begin{array}{l}.000 \\
.000\end{array}$ \\
\hline
\end{tabular}

\section{Simple Regression Equations is $\mathrm{Y}=13,834+0,517 \mathrm{X}$}

Correlation coefficient 0.664 correlation is in the interval from 0.600 to 0.799 which belong to the level of a strong relationship 
TABLE IV. OutPut EFFECT OF LIFESTYLE ON THE PURCHASE DeCISION

\begin{tabular}{|c|c|c|c|c|}
\hline \multicolumn{1}{|c|}{ Model } & \multicolumn{2}{|c|}{ Rodel Summary } \\
\hline 1 & & R Square & $\begin{array}{c}\text { Adjusted R } \\
\text { Square }\end{array}$ & $\begin{array}{c}\text { Std. Error } \\
\text { of the } \\
\text { Estimate }\end{array}$ \\
\hline \multicolumn{6}{|c|}{} & & .435 & 3.256 \\
\hline \multicolumn{4}{|c|}{$\begin{array}{l}\text { a. Predictors: (Constant), LIFESTYLE ANALYSIS } \\
\text { b. Dependent Variable: DECISION MEMBER }\end{array}$} \\
Source: Data Processing using SPSS 17.0 for Windows
\end{tabular}

Based on Table 4, the R-square value or the coefficient of determination is 0.664 . This figure has meaning R-square values ranged numbers from 0 to $1, \mathrm{R}$-square value is close to 1 indicates that the model is formulated to explain the purchase decision very well. Table 4:16 shows that lifestyle contributes analysis on purchasing decisions by $44.0 \%$, while the remaining $100 \%-44.0 \%=56.0 \%$ are influenced by other factors.

Processing results above show that lifestyle affects of $44.0 \%$ on purchasing decisions, while the remaining $56.0 \%$ is influenced by factors or other variables outside variables studied.

\section{CONCLUSIONS AND RECOMMENDATIONS}

\section{Conclussion}

- Overall perception of lifestyle conditions located on the Gold's Gym Bandung Braga City Walk is at very high category is opinion. This is because Gold's Gym Due to Gold's Gym has the facility to be operational services make members already believe and assess the best opinion. While the lowest indicator is activity due to the difference in activity between men and women at different fitness center as well as the purpose of the exercise was also different.

- Overall perception of the decision to become a member of Gold's Gym in the category is also very high with purchasing decisions indicators become a member of the most good is the selection of brands.

- Lifestyle indicators that consist of activity, interest, opinion and demographics provide a strong and positive influence on purchasing decisions become a member of Gold's Gym Braga City Walk Bandung to show a high degree of correlation.

\section{Recommendations}

- Gold's Gym Braga City Walk Bandung need to separate free weight area between men and women into two rooms.

- Gold's Gym Braga City Walk Bandung needs to better manage and empower facilities of Gold's Gym by cooperating with The Kiosk, Sugarush, NAV Family Karaoke or else.

- For future studies are expected researchers to more broadly study as to analyze and weigh other factors affecting such loyalty member, Customer Relationship Management and Customer Satisfaction to be more consistent to maintain the quality and quantity of Gold's Gym from operating divisions consisting of customer service, relationship marketing, personal trainer until cleaning service.

\section{REFERENCES}

[1] Kotler, Philip dan Kevin Lane Keller. 2012. Marketing Management 14th Edition. New Jersey : Pearson Prentice Hall.

[2] http://www.goldsgym.co.id/

[3] Solomon, Michael R. 2011. Consumer Behaviour 9th Edition. New Jersey : Pearson Education.

[4] Schiffman. Len G dan Leslie L Kanuk. 2010. Consumer Behaviour, 5th Edition. New Jersey : Pretince Hall.

[5] Ali Hasan. 2009. Marketing. Yogyakarta : Media Pressindo.

[6] Silvya . 2009. Journal of Lifestyle Influence Decision Against Consumer Purchase, Vol 6 No. 1:92-100.

[7] Fauzan Irhamni 2010, Efforts to Maintain The decision of stay of Grand Kemang Hotel through Lifestyle Analysis (Survey On Individual guest staying at Grandkemang Hotel Jakarta)

[8] Ratna Yuliana 2008, Lifestyle influence on the buying decisionApparel Batik Danar Hadi (Consumer Studies Women At Outlet Dana Hadi Diponegoro Surabaya)

[9] Yulia Widiastuti 2009. Lifestyle Environmental Practices On Bicycle Community, KRL and Trans Jakarta in Jakarta

[10] Eriska Rulistianti 2011, Lifestyle behavior influence on consumer purchasing decisions automatic scooter Honda Scoopy 